\title{
Uji daya hambat ekstrak biji buah alpukat (Persea americana Mill.) terhadap pertumbuhan Streptococcus mutans
}

\author{
${ }^{1}$ Anggriana H. Bujung \\ ${ }^{2}$ Heriyannis Homenta \\ ${ }^{3}$ Johanna A. Khoman \\ ${ }^{1}$ Kandidat Skripsi Program Studi Pendidikan Dokter Gigi Fakultas Kedokteran \\ ${ }^{2}$ Bagian Mikrobiologi Fakultas Kedokteran \\ ${ }^{3}$ Program Studi Pendidikan Dokter Gigi Fakultas Kedokteran \\ Universitas Sam Ratulangi Manado \\ Email: anggriana.bujung@gmail.com
}

\begin{abstract}
In addition to daily consumption, avocado is also used to treat oral diseases. Scientific studies showed that avocado seed contained flavonoids, tannins, and alkaloid which were expected to inhibit bacterial growth. This study was aimed to obtain the bacterial inhibitory effect of avocado seed (Persea americana Mill.) extract on Streptococcus mutans as the primary cause of dental caries. This was a true experimental study with the post test only control group design. This study used a modified Kirby-Bauer method with paper disk. The positive control was erythromycin and the negative control was aquadest. Avocado seeds were extracted by using maceration method with $96 \%$ ethanol. The Streptococcus mutans bacteria were obtained from pure stock of Microbiology Laboratory of Pharmacy Study Program University of Sam Ratulangi Manado. The results showed that the mean diameter of inhibition zone of avocado seed extract was $21.8 \mathrm{~mm}$ which was classified as very strong inhibition. Conclusion: Persea Americana Mill. seed extract had a very strong inhibitory effect on the growth of Streptococcus mutans.
\end{abstract}

Keywords: avocado seed (Persea americana Mill.), Streptococcus mutans, inhibition effect

\begin{abstract}
Abstrak: Selain menjadi bahan konsumsi masyarakat yang lezat, ternyata alpukat telah lama dipercaya dapat mengobati penyakit di dalam rongga mulut. Di dalam buah alpukat terdapat biji yang terbukti melalui penelitian ilmiah mengandung flavonoid, alkaloid, dan tannin yang mampu menghambat pertumbuhan bakteri. Penelitian ini bertujuan untuk mengetahui daya hambat ekstrak biji buah alpukat (Persea americana Mill.) terhadap pertumbuhan Streptococcus mutans. Jenis penelitian ialah eksperimental murni dengan post test only control group design. Metode yang digunakan ialah modifikasi Kirby-Bauer dengan paper disk. Kontrol positif menggunakan antibiotik eritromisin dan kontrol negatif menggunakan akuades. Biji buah alpukat diekstraksi dengan metode maserasi menggunakan pelarut etanol $96 \%$. Bakteri Streptococcus mutans diambil dari stok bakteri murni Laboratorium Mikrobiologi Program Studi Farmasi Fakultas MIPA Universitas Sam Ratulangi Manado. Hasil penelitian menunjukkan diameter rerata zona hambat dari ekstrak biji buah alpukat yang terbentuk ialah 21,8 mm dan digolongkan sebagai zona hambat sangat kuat. Simpulan: Ekstrak biji buah alpukat memiliki daya hambat sangat kuat terhadap pertumbuhan Streptococcus mutans.

Kata kunci: biji buah alpukat (Persea americana Mill.), Streptococcus mutans, daya hambat
\end{abstract}

Karies gigi berasal dari bahasa latin yang artinya lubang pada gigi. Karies merupakan penyakit pada jaringan keras gigi yang ditandai dengan rusaknya lapisan email, dentin, dan sementum pada gigi yang disebabkan oleh aktivitas metabolisme bakteri. ${ }^{1}$ Streptococcus mutans merupakan salah satu bakteri yang terdapat dalam mulut dan berperan penting 
dalam proses terjadinya karies gigi. ${ }^{2}$ Karies gigi dapat menyerang semua tingkatan usia dan semua ras di dunia dengan prevalensi yang meningkat pesat di banyak negara sehingga telah menjadi masalah umum di masyarakat dan perlu mendapat perhatian yang serius. $^{3}$ Berdasarkan Riset Kesehatan Dasar (Riskesdas) pada tahun 2013, prevalensi nasional masalah gigi dan mulut di atas angka nasional. Provinsi Sulawesi Utara merupakan salah satu provinsi dengan prevalensi sebesar $31,6 \%{ }^{4}$

Saat ini telah banyak penelitian yang dilakukan dengan menggunakan tanaman herbal alami sebagai alternatif dalam bidang pengobatan, salah satunya ialah biji alpukat. Berdasarkan hasil fitokimia diketahui bahwa biji alpukat memiliki senyawa metabolit sekunder seperti flavonoid, saponin, tannin, alkaloid, dan terpenoid yang merupakan komponen aktif sebagai antibakteri. ${ }^{5}$

Penelitian yang dilakukan oleh Idris et al. ${ }^{6}$ mengenai efek ekstrak etilasetat biji alpukat (Persea americana Mill.) 3,25 gr terhadap Staphylococcus aureus dan Streptococcus pyogenes menunjukkan adanya aktivitas antibakteri dengan masing-masing zona hambat $37 \mathrm{~mm}$ dan $25 \mathrm{~mm}$. Penelitian yang dilakukan oleh Asri $^{7}$ mengenai efek antibakteri ekstrak etanol biji alpukat (Persea americana Mill.) sebagai alternatif bahan irigasi terhadap Enterococcus faecalis melaporkan bahwa konsenrasi $10 \%$ ekstrak biji alpukat masih menunjukkan daya antibakteri dengan diameter zona hambat 2,3 $\pm 0,12 \mathrm{~mm}$.

Penelitian ini dapat memberikan informasi mengenai daya hambat bakteri dari ekstrak biji buah alpukat (Persea americana Mill.) yang dapat menjadi acuan bagi penelitian selajutnya.

\section{BAHAN DAN METODE PENELITIAN}

Jenis penelitian ini ialah eksperimental dengan post-test only control group design. Penelitian ini dilaksanakan di Laboratorium Mikrobiologi Farmasi Fakultas MIPA Universitas Sam Ratulangi Manado pada bulan Oktober 2016-Maret 2017. Subjek dari penelitian ialah efek ekstrak biji buah alpukat (Persea americana Mill.) terhadap pertumbuhan Streptococcus mutans.

Metode pengujian yang digunakan merupakan metode modifikasi Kirby-Bauer dengan menggunakan kertas saring. Bakteri Streptococcus mutans yang disimpan di media agar diperoleh dari stok bakteri murni Laboratorium Farmasi Fakultas MIPA Universitas Sam Ratulangi Manado

Bakteri Streptococcus mutans diambil dengan jarum ose, lalu ditanamkan pada media agar miring dengan cara menggores. Bakteri yang telah digores pada media agar diinkubasi dalam inkubator pada suhu $37^{\circ} \mathrm{C}$ selama $1 \times 24$ jam. Bakteri yang telah diinkubasi diambil koloninya dari media agar miring dengan menggunakan jarum ose steril kemudian dimasukan ke dalam media BHI-B sampai kekeruhnya sama dengan standar McFarland. Lidi kapas steril dicelupkan ke dalam suspensi bakteri hingga basah. Lidi kapas diperas dengan menekankan pada dinding tabung reaksi bagian dalam, kemudian digores merata pada media MHA sampai permukaannya tertutup.

Selanjutnya kertas saring pertama dicelupkan ke dalam wadah kaca berisi ekstrak biji buah alpukat konsentrasi $100 \%$, kertas saring kedua dicelupkan dengan kontrol positif yaitu eritromisin $15 \mu \mathrm{g}$, dan kertas saring ketiga dicelupkan ke dalam akuades sebagai kontrol negatif. Ketiga kertas saring tersebut diletakan di atas media MHA yang sudah ditanamkan bakteri kemudian cawan Petri diinkubasi dalam inkubator dalam suhu $37^{\circ} \mathrm{C}$ selama $1 \times 24$ jam. Pengamatan dilakukan setelah 24 jam masa inkubasi. Diameter vertikal dan diameter horizontal zona hambat yang terbentuk di sekitar paper disk diukur dalam satuan milimeter (mm) menggunakan penggaris.

\section{HASIL PENELITIAN}

Cawan Petri yang telah diinkubasi selama 24 jam pada suhu $37^{\circ} \mathrm{C}$ dalam inkubator diambil lalu dilihat zona hambat yang terbentuk, kemudian zona hambat tersebut diukur dengan menggunakan penggaris dalam satuan milimeter dan dimasukan dalam tabel pengamatan. Tabel 1 menunjukkan bahwa diameter rerata zona hambat ekstrak biji buah alpukat yaitu 21,8 mm sedangkan zona hambat kontrol positif antibiotik eritromisin sebesar $35,5 \mathrm{~mm}$ dan kontrol negatif akuades tidak menunjukkan adanya zona hambat. 
Jurnal e-GiGi (eG), Volume 5 Nomor 2, Juli-Desember 2017

Tabel 1. Hasil pengukuran diameter zona hambat bakteri Streptococcus mutans

\begin{tabular}{|c|c|c|c|}
\hline \multirow[b]{2}{*}{ Perlakuan } & \multicolumn{3}{|c|}{ Diameter zona hambat (mm) } \\
\hline & $\begin{array}{c}\text { Ekstrak biji buah } \\
\text { alpukat }\end{array}$ & $\begin{array}{c}\text { Kontrol positif } \\
\text { (eritromisin) }\end{array}$ & $\begin{array}{l}\text { Kontrol negatif } \\
\text { (akuades) }\end{array}$ \\
\hline I & 21,5 & 38,5 & 0 \\
\hline II & 27,5 & 35 & 0 \\
\hline III & 25 & 32,5 & 0 \\
\hline IV & 17,5 & 37 & 0 \\
\hline V & 17,5 & 34,5 & 0 \\
\hline Rerata & 21,8 & 35,5 & 0 \\
\hline
\end{tabular}

\section{BAHASAN}

Penelitian ini merupakan uji eksperimental laboratorik untuk mengetahui ada tidaknya daya hambat ekstrak biji buah alpukat (Persea americana Mill.) terhadap bakteri Streptococcus mutans. Pada penelitian ini, bakteri Streptococcus mutans dibiakkan dalam media MHA disertai dengan peletakan kertas saring yang diberi ekstrak biji buah alpukat (Persea americana Mill.) yang diencerkan dengan akuades. Peletakan kertas saring antibiotic eritromisin $15 \mu \mathrm{g} / \mathrm{ml}$ sebagai kontrol positif serta peletakan kertas saring yang direndam dalam akuades sebagai kontrol negative, lalu diinkubasi selama 24 jam.

Berdasarkan hasil pengamatan terhadap lima cawan petri terlihat adanya zona hambat yang terbentuk di sekitar kertas saring yang di beri ekstrak biji buah alpukat (Persea americana Mill.). Rerata diameter zona hambat yang terbentuk pada esktrak biji buah alpukat (Persea americana Mill.) setelah lima kali pengulangan ialah $21,8 \mathrm{~mm}$ yang termasuk dalam kategori zona hambat sangat kuat menurut klasifikasi Davis dan Stout. Kategori zona hambat menurut Davis dan Stout terbagi atas tidak ada zona hambat; kategori lemah yaitu kurang dari $5 \mathrm{~mm}$; kategori sedang yaitu 5-10 mm; kategori kuat yaitu zona hambat 11$20 \mathrm{~mm}$; dan kategori sangat kuat yaitu lebih dari $20 \mathrm{~mm}^{8}$

Perbandingan hasil ekstrak biji buah alpukat dengan antibiotik eritromisin menunjukkan zone hambat kertas saring yang telah diberi ekstrak biji buah alpukat (Persea americana Mill.) lebih kecil dari kertas saring obat antibiotik eritromisin, sedangkan kertas saring yang telah diberi akuades tidak menunjukkan zona hambat. Hasil diameter zone hambat ekstrak biji buah alpukat (Persea americana Mill.) yang lebih kecil daripada antibiotik eritromisin dipengaruhi oleh minimal inhibitory concentration (MIC) eritromisin yang telah diketahui, sedangkan kemampuan ekstrak biji buah alpukat belum diketahui konsentrasi paling tepat untuk menghambat pertumbuhan bakteri Streptococcus mutans.

Uji daya hambat ekstrak biji buah alpukat (Persea americana Mill.) terhadap bakteri Streptococcus mutans merupakan penelitian yang belum pernah dilakukan sebelumnya, tetapi untuk uji daya hambat ekstrak biji buah alpukat terhadap bakteri infeksi lainnya sudah pernah dilakukan sebelumnya. Penelitian Idris et al. ${ }^{6}$ menggunakan ekstrak etil asetat biji alpukat (Persea americana Mill.) 3,25 gram terhadap Staphylococcus aureus dan Streptococcus pyogenes menunjukkan adanya aktifitas antibakteri terhadap kedua bakteri tersebut. Penelitian sebelumnya juga pernah dilakukan menggunakan bakteri yang sama tetapi dengan ekstrak yang berbeda oleh Bontjura $^{10}$ pada tahun 2015, yaitu uji efek antibakteri daun leilem terhadap pertumbuhan bakteri Streptococcus mutans dengan hasil zona hambat sebesar $21,8 \mathrm{~mm}$.

Antibakteri eritromisin dijadikan sebagai kontrol positif karena eritromisin merupakan antibakteri pilihan yang memiliki kepekaan terhadap kelompok bakteri Gram positif, seperti bakteri Streptococcus mutans. Selain itu, eritromisin memiliki spektrum antibakteri yang mirip dengan penisilin sehingga dapat digunakan sebagai alternatif pada pasien yang alergi terhadap penisilin. Eritromisin merupakan antibiotik golongan makrolid yang memiliki cincin akton besar dalam rumus molekulnya. Golongan makrolid menghambat sintesis protein kuman dengan jalan berikatan secara reversibel dan umumnya bersifat bakteriostatik. ${ }^{11}$

Ekstrak biji buah alpukat (Persea 
americana Mill.) telah diketahui mengandung berbagai senyawa yang bersifat antibakteri seperti flavonoid, saponin, dan tannin. Mekanisme kerja flavonoid sebagai antimikroba dapat dibagi menjadi tiga yaitu menghambat sintesis asam nukleat, menghambat fungsi membran sel, dan mrnghambat metabolisme energi. Flavonoid menyebabkan terjadinya kerusakan dinding sel bakteri, mikrosom, dan lisosom sebagai hasil interaksi antara flavonoid dengan DNA bakteri. Mekanisme kerja saponin sebagai antibakteri yaitu dapat menyebabkan kebocoran protein dan enzim dari dalam sel. Saponin dapat menjadi antibakteri karena zat aktif permukaannya mirip deterjen, sehingga saponin dapat menurunkan tegangan permukaan dinding sel bakteri dan merusak permeabilitas membrannya yang berakibat sitoplasma keluar dari dalam sel yang berlanjut dengan kematian sel. Mekanisme kerja tannin yaitu menghambat enzim reverse transcriptase dan DNA topoisomerase sehingga sel bakteri tidak terbentuk. Efek antibakteri tanin berhubungan dengan kemampuannya untuk menginaktifkan adesi sel mikroba, menginaktifkan enzim, dan mengganggu transpor protein pada lapisan dalam sel. ${ }^{11}$

Penelitian ini menunjukkan bahwa ekstrak biji buah alpukat (Persea americana Mill.) memiliki daya hambat terhadap bakteri Streptococcus mutans yang sangat kuat. Diharapkan ekstrak biji buah alpukat kedepannya dapat dikembangkan dan diolah menjadi sediaan obat atau bahan campuran pasta gigi untuk mengobati karies gigi dan infeksi rongga mulut lainnya.

\section{SIMPULAN}

Ekstrak biji buah alpukat (Persea americana Mill.) memiliki daya hambat sangat kuat terhadap pertumbuhan Streptococcus mutans.

\section{SARAN}

Diharapkan dapat dilakukan penelitian lebih lanjut mengenai uji daya hambat kadar minimum ekstrak biji buah alpukat (Persea americana Mill.) terhadap pertumbuhan Streptococcus mutans, sehingga dapat di ketahui minimal inhibitory concentration ekstrak biji buah alpukat terhadap pertumbuhan Streptococcus mutans.

Juga perlu dilakukan penelitian lebih lanjut tentang efektivitas antibakteri esktrak biji buah alpukat (Persea americana Mill) agar menjadi alternatif obat di bidang kedokteran gigi dan masyarakat luas guna penanggulangan infeksi Streptococcus mutans.

\section{DAFTAR PUSTAKA}

1. Malinggas F. Uji daya hambat ekstrak biji buah mengkudu ( $M$ citrofolia $\mathrm{L}$ ) terhadap pertumbuhan Streptococcus mutans secara in vitro [Skripsi], Manado: Program Studi Pendidikan Dokter Gigi Fakultas Kedokteran Universitas Sam Ratulangi; 2015.

2. Assagaf A, Wowor M, Supit A. Uji efek antibakteri ekstrak lidah buaya (Aloe vera) dalam menghambat pertumbuhan koloni Streptococcus mutans secara in vitro. Dentire. 2012;1(1).

3. Hongini SY, Aditiaramarwan $M$. Kesehatan Gigi dan Mulut. Bandung: Pustaka Reka Cipta, 2012; p. 146-7.

4. Badan Penelitian dan Pengembangan Kesehatan Republik Indonesia. Laporan Hasil Riset Kesehatan Dasar (Riskesdas) Nasional. Jakarta: Kementerian Kesehatan Republik Indonesia, 2013; p. 146-7.

5. Jimenez-Arellanes A, Luna-Herrera J, Ruiz-Nicolas R, Cornejo-Garrido J, Tapia A, Yepez-Mulia L. Antiprotozoal and antimycobacterial activity screening and antimicrobial activity of seed extract of Persea americana seeds. BMC Complement Altern Med. 2013;13(13):109.

6. Idris S, Ndukwe GI, Gimba CE. Preliminary phytochemical screening and antimicrobial activity of seed extract of Persea americana (Avocado pear). Bajopas. 2009;2(1):173-6.

7. Asri D. Efektivitas antibakteri ekstrak etanol biji alpuat (Persea americana) sebagai bahan irigasi saluran akar terhadap pertumbuhan bakteri Enterococcus faecalis [Skripsi]. Surakarta: FKG UMS; 2014.

8. Setiabudy, Rianto. Farmakologi dan Terapi (5th ed). Jakarta: Departemen Farmakologi dan Terapeutik Fakultas Kedokteran Universitas Indonesia, 2007; p. 585-6, 723-4.

9. Hendra R, Ahmad S, Sukari A, Shukor MY, Oskoueian E. Flavonoid analyses and antimicrobial activity of 
Jurnal e-GiGi (eG), Volume 5 Nomor 2, Juli-Desember 2017

various parts of Phaleria macrocarpa (Scheff.) boerl fruit. Int $\mathbf{J}$ Mol Sci. 2011;12(6):3422-31.

10. Bontjura S, Waworuntu OA, Siagian KV. Uji efek antibakteeri ekstrak daun leilem (Clerodendrum minahassae L.) terhadap bakteri Streptococcus mutans. Pharmacon. 2015;4(4).

11. Omojate GC, Enwa FO, Jewo Ao, Eze CO. Mechanism of antimicrobial actions of phytochemica against enteric pathogens - A review. J Pharm Chem Biol Sci. 2014;2(2):77-85. 